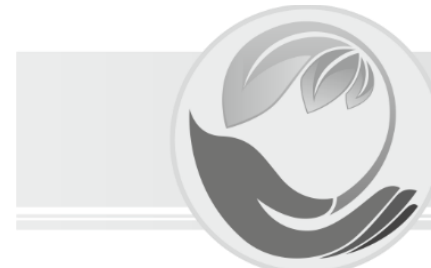

УДК 504.064.4:658.567.1
Механіка агротехнологічних матеріалів Mechanics of agrotechnological materials

\title{
Гранульований доменний шлак як сорбент органічних барвників
}

\author{
І.В. Грайворонська ${ }^{1}$, Е.Б. Хоботова ${ }^{2}$, В.В. Даценко ${ }^{3}$, І.А. Черепньов ${ }^{4}$ \\ 1, 2, з Харківський національний автомобільно-дорожній університет (м. Харків, Україна) \\ ${ }^{4}$ Харківський національний технічний університет сільського господарства \\ імені Петра Василенка, (м. Харків, Україна) \\ email:1inna_gra@ukr.net; ${ }^{2}$ elinahobotova@gmail.com; ${ }^{3}$ dacenkovita14@gmail.com; \\ ${ }^{4}$ voenpred314@ukr.net
}

\begin{abstract}
Визначено властивості гранульованого доменного шлаку «АрселорМіттал Кривий Ріг», що зумовлюють його сорбційну активність. У складі фракцій шлаку ідентифіковані мінерали: окерманіт $\mathrm{Ca}_{2} \mathrm{MgSi}_{2} \mathrm{O}_{7}$, геленіт $\mathrm{Ca}_{2} \mathrm{Al}(\mathrm{Al}, \mathrm{Si})_{2} \mathrm{O}_{7}$, ранкініт $\mathrm{Ca}_{3} \mathrm{Si}_{2} \mathrm{O}_{7}$, псевдоволластоніт $\mathrm{CaSiO}_{3}$, мервініт $\mathrm{Ca}_{3} \mathrm{MgSi}_{2} \mathrm{O}_{8}$, мікроклін $\mathrm{KAISi}_{3} \mathrm{O}_{8}$, кальцит $\mathrm{CaCO}_{3}$, ольдгаміт $\mathrm{CaS}$ з вмістом алюмосилікатів кальцію і магнію $>50$ \%. Деякі фрази знаходяться в аморфному сорбційно-активному стані. Показана доцільність активації водою протягом 1 доби, в результаті якої на поверхні утворюються і дисоціюють гідроксильні і гідрофрільні силанольні групи з формуванням негативного заряду поверхні шлакових частинок, що характерно для алюмосилікатів $\mathrm{Ca}$ i $\mathrm{Mg}$, а також мінералів кальциту і ольдгаміту. Форма ізотерми адсорбції свідчить про утворення полімолекулярних шарів органічного барвника метиленового синього (МС), що збільшує ефективність шлакового сорбенту. Величина адсорбції MC не менш 2 мг/г. Показано відсутність десорбції MC з шлаку, що забезпечує безпеку як захоронення відпрацьованого сорбенту, так і його утилізації в якості наповнювача будівельних матеріалів. Доведено радіаційну безпеку шлаку. Питома ефективна активність фракцій шлаку не перевищує 370 Бк/кг, що дозволяє його використання в якості технічних матеріалів без обмежень. Запропоновано технологічну схему адсорбційної очистки стічних вод підприємств органічного синтезу і текстильної промисловості, що містять органічні барвники, за допомогою шлакового сорбенту. Стадії технологічного процесу: надходження шлаку з відвалу, аналіз мінерального складу шлаку, водна активація шлаку, статична сорбція барвників в відстійнику, подальша утилізація шлаку і надходження очищених вод в первинне виробництво. Технологія передбачає видалення органічних барвників із стічних вод і їх повторне використання, що забезпечує замкнутість циклу оборотного водоспоживання, відсутність витрат хімічних реагентів на активацію шлакового сорбенту, поліпшення екологічної ситуації в місцях розташування шлакових відвалів за рахунок використання шлаків в якості сорбентів.
\end{abstract}

Ключові слова: сорбція, гранульований доменний шлак, органічні барвники, величина адсорбції, активація шлаку, адсорбційний процес, очистка розчину

Постановка проблеми та її актуальність. В адсорбційних технологіях можливе використання різних матеріалів природного і промислового походження [1]. Впровадження маловідходних технологій обумовлює необхідність виявлення ресурсної цінності та корисних властивостей промислових відходів, обґрунтування доцільності їх утилізації як технічних матеріалів і сорбентів при очищенні промислових стічних вод. Ефеективність очищення стічних вод за допомогою сорбентів техногенного походження може досягати 95 \% [2]. Показано можливості застосування різних видів про- мислових відходів: на червоному шламі доведена сорбція фоссрат-іонів [3], модифіковані відходи целюлозних текстильних відходів використовують для очищення стічних вод від іонів металів [4], термічно модифрікований вуглецевміщуючий шунгіт в поєднанні з оксихлоридом Al застосовують в комбінованій очистці стічних вод від Fe (III) [5]. Матеріали неорганічного походження також можливо використовувати для сорбції органічних сполук, наприклад, нафртопродуктів [6] або френолу [7] в режимі періодичної адсорбції з використанням модифрікованих промислових твердих відходів в 
присутності катіонних і аніонних поверхнево-активних речовин (ПАР). На шлаковому цементі проведена сорбція катіонної поверхнево-активної речовини $\left[\mathrm{CH}_{3}\left(\mathrm{CH}_{2}\right)_{11} \mathrm{~N}\left(\mathrm{CH}_{3}\right)_{3}\right] \mathrm{Cl}$ з величиною адсорбції 12,8 мг/г [8]. Показано, що барвник для текстилю Reactive Blue 19 поглинається бентонітом, модифікованим катіонною поверхнево-активною речовиною [9]. Вугільна летюча зола успішно використовується для сорбції органічних барвників [10-12]. Проведена сорбція барвників на гранулах вугільної летючої золи немодифікованої і модифікованої ПАР гексадецілтриметіламмонійбромідом [13]. Шаруваті силікати, модифіковані катіонними поліелектролітами сорбують аніонні органічні барвники [14]. Проведена еколого-хімічна оцінка металургійних шлаків як сорбентів з визначенням напряму практичного використання $[15,16]$. Вивчена сорбція метиленового синього (МС), Конго червоного (КЧ) та метілвіолету (МВ) металургійним шлаком виробництва сплаву $\mathrm{Fe}-\mathrm{Ni}$, з основним мінералом діопсидом $\mathrm{CaMg}\left(\mathrm{Si}_{2} \mathrm{O}_{6}\right)[17,18]$.

Мета дослідження - обґрунтувати можливість використання гранульованого доменного шлаку «АрселорМіттал Кривий Ріг» в якості сорбенту органічних барвників з розробкою технологічної схеми адсорбційного очищення стічних вод із забезпеченням замкнутості циклу оборотного водоспоживання. Для досягнення мети необхідно визначити мінералогічний склад шлаку, довести його радіаційну безпеку, охарактеризувати поверхню шлаку (питому площу поверхні, заряд частинок), визначити сорбційну активність шлаку по відношенню до МС

Методи дослідження. Мінералогічний склад шлаку визначено за допомогою рентгенофазового аналізу, проведеного на порошковому дифрактометрі Siemens D500 в мідному випромінюванні з графітовим монохроматором. Первинний пошук фраз виконаний по картотеці PDF-1 [19], розрахунок рентгенограм виконано за методом Ритвельда з використанням програми FullProf [20].

Мікрофотографії поверхні шлакових частинок отримані на скануючому електронному мікроскопі JSM-6390 LV.

Питомі активності природних радіонуклідів шлаку $\left(C_{i}\right)$ визначені гамма-спектрометричним методом за допомогою сцинтиляційного гаммаспектрометру СЕГ-001 «АКП-С». За результатами гамма-спектрометричного дослідження розраховані величини питомих ефективних активностей фракцій шлаку $C_{\text {еф }}$ за фрормулою [21]:

$$
\mathrm{C}_{э \phi}=\mathrm{C}_{\mathrm{Ra}}+1,31 \mathrm{C}_{\mathrm{Th}}+0,085 \mathrm{C}_{\mathrm{K}}, \quad \text { Бк/кг. }
$$

Сорбція органічного барвника МС вивчена спектрофротометрично за допомогою SPEKOL 11. Beличина адсорбції (а) розрахована за фрормулою:

$$
a=\frac{\left(\mathrm{C}_{1}-\mathrm{C}_{2}\right) \cdot V}{m},
$$

$\mathrm{Mr} / \Gamma$,

де: $\mathrm{C}_{1}$ та $\mathrm{C}_{2}$ - концентрації сорбату (MC) до та після сорбції, мг/дм³ $V$ - обсяг розчину, дм³; $m$ - маса сорбенту, г.

Початкова концентрація МС 10-20 мг/дм³ порівнянна з концентрацією органічних барвників в промивних водах текстильного виробництва [22-24].

Питома поверхня шлаку S визначена методом повітропроникності на приладі TQD-G1, дорівнює $1625 \mathrm{~cm}^{2} / г$ для фрракції шлаку $<6,3 \cdot 10^{-4}$ м. Невелика величина $S$ свідчить про недостатню розвиненість поверхні шлаку, щоб бути основною причиною його сорбційної активності.

Заряд частинок шлаку і величина електрокінетичного потенціалу визначалися методом макроелектрофрорезу суспензії. Використовувалася гранулометрична фрракція 6,3·10-4 м. Наявність поверхневих силанольних груп, що дисоциюють 3 відщепленням $\mathrm{H}^{+}$, визначає негативний заряд поверхні частинок шлаку. Електрокінетичний потенціал розрахований за формулою, що враховує довжину просування кордону суспензії до позитивного електроду $\left(h=2,633 \cdot 10^{-3} \mathrm{~m}\right)$ та час руху кордону (659,5 c). Величина $\xi$-потенціалу 11,7 мВ відповідає середньому $\xi$-потенціалу сферичних частинок мінеральних суспензій.

Мінералогічний склад шлаку. Рентгенофазовий аналіз шлаку показав присутність мінеральних фраз (фракція >10 мм), \%: кальцит $\mathrm{CaCO}_{3}$ $(33,2)$, окерманіт $\mathrm{Ca}_{2} \mathrm{MgSi}_{2} \mathrm{O}_{7} \quad(5,5)$, геленіт $\mathrm{Ca}_{2} \mathrm{Al}(\mathrm{Al}, \mathrm{Si})_{2} \mathrm{O}_{7}(24,6)$, ранкініт $\mathrm{Ca}_{3} \mathrm{Si}_{2} \mathrm{O}_{7}(4,8)$, псевдоволластоніт $\mathrm{CaSiO}_{3}(4,3)$, мервініт $\mathrm{Ca}_{3} \mathrm{MgSi}_{2} \mathrm{O}_{8}$ $(6,1)$, мікроклін $\mathrm{KAISi}_{3} \mathrm{O}_{8}(6,5)$, ольдгаміт $\mathrm{CaS}$ $(15,1)$. Хвилеподібний характер дифрактограм шлаку пов'язаний з наявністю аморфних фаз. На рентгенограмах фрракцій шлаку <0,63 мм та 1,252,5 мм зареєстрований розмитий максимум на фоні в області кутів 20-40. Склоподібна структура видна на мікрофротографіях шлакових частинок, що відносяться до різних фракцій (рис. 1). При швидкому охолодженні гранульовані шлаки не встигають повністю закристалізуватися, тому володіють хімічною, сорбційною і гідравлічною активністю. Таким чином, сорбційні властивості шлаку можуть обумовлюватися високою концентрацією (>50 \%) алюмосилікатів Са та Mg і наявністю аморфних сполук.

Радіонуклідний склад шлаку. При використанні шлаків як сорбентів повинна бути забезпечена їх радіаційна безпека. Найбільш імовірним механізмом накопичення природних радіонуклідів $€$ гетеровалентне ізоморфне заміщення в структурах мінералів шлаків [25]. В таблиці 1 представлені результати гамма-спектрометрич- 
ного аналізу фракцій шлаку. Радіонуклідний склад фракцій відрізняється один від одного, особливо за ізотопом ${ }^{40}$ К. Активність ${ }^{232}$ Тh суттєво не змінюється. СRа збільшується у 1,35 рази з підвищенням дисперсності фракцій і досягає максимальної величини 91 Бк/кг. Найвищі значення $C_{\text {еф }}$ зареєстровані для дрібних фрракцій <1,25 мм. Найбільш радіаційно-чистими є великі фракції

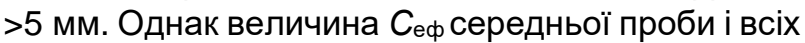
фрракцій шлаку не перевищує 370 Бк/кг, тому шлакові фрракції можуть використовуватися без обмежень як технічний матеріал [21].

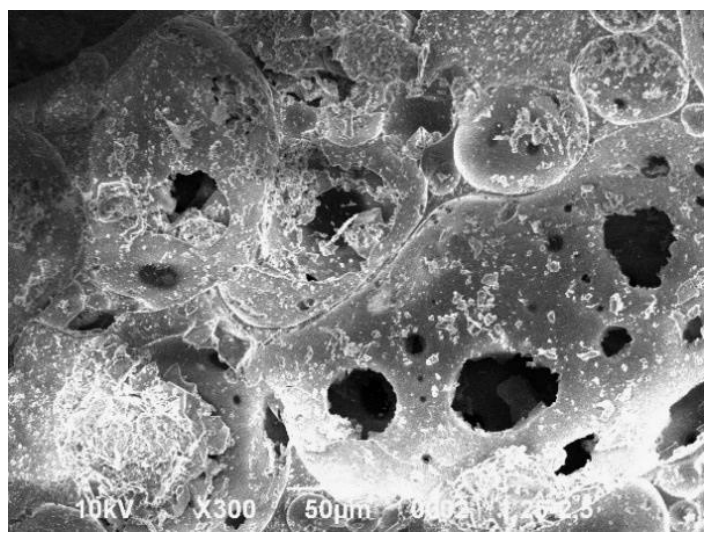

a

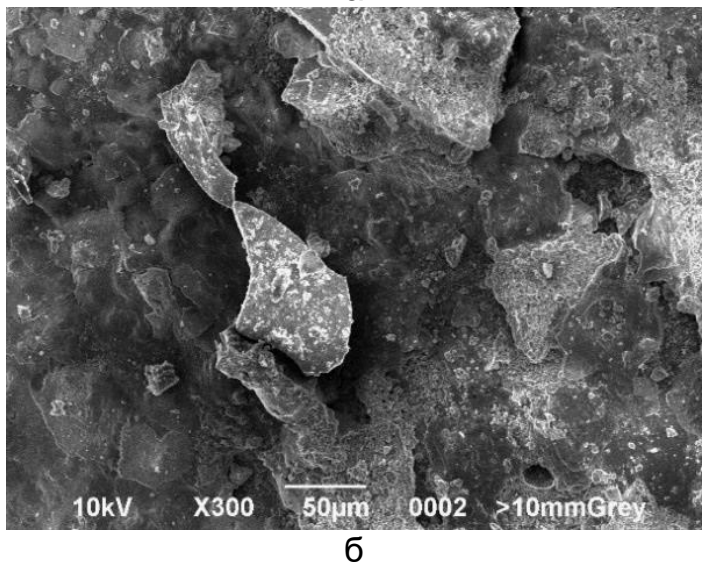

Рис. 1. Мікрофотографії поверхні частинок гранульованого доменного шлаку при збільшенні х 300, фрракцій, мм: а) 1.25-2.5; б) >10

Сорбційні характеристики шлаку. Основну кількісну характеристику сорбційної активності шлаку - величину адсорбції (а) визначали в статичному режимі. Використана для підвищення сорбційної активності шлаку хімічна активація водою та розчинами 0,5 $\mathrm{M} \mathrm{H}_{2} \mathrm{SO}_{4}$ та $1 \mathrm{M} \mathrm{NaOH}$ показала, що величина адсорбції амс за певний період часу не залежить від виду активатора. Протягом 24 год. а досягає величини 0,2 мг/г. При незначному варіюванні швидкості сорбції після дії різних активаторів, з метою економії хімічних реагентів і виключення стадії промивання шлаку від активатора рекомендується попередня обробка водою протягом 24 годин. За експериментальними даними побудована ізотерма адсорбції (рис. 2).

Таблиця 1. Результати гаммаспектрометричного аналізу фракцій гранульованого доменного шлаку

\begin{tabular}{|c|c|c|c|c|}
\hline \multirow[b]{2}{*}{$\begin{array}{c}\text { Грануломе- } \\
\text { трична фрра- } \\
\text { кція, мм }\end{array}$} & \multirow[b]{2}{*}{$\begin{array}{l}C_{\text {eфp, }} \\
\text { Бк/Кг }\end{array}$} & \multicolumn{3}{|c|}{$C_{i}$, Бк/кг } \\
\hline & & 남 & $\begin{array}{l}\underset{\widetilde{N}}{\sim} \\
\underset{\sim}{\stackrel{N}{N}}\end{array}$ & 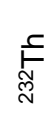 \\
\hline $\begin{array}{c}\text { Середня } \\
\text { проба }\end{array}$ & $127 \pm 15$ & 116 & 85 & 25 \\
\hline$>10$ & $117 \pm 17$ & 209 & 67 & 24 \\
\hline $5-10$ & $119 \pm 18$ & 244 & 65 & 25 \\
\hline $2,5-5$ & $131 \pm 18$ & 269 & 75 & 26 \\
\hline $1,25-2,5$ & $153 \pm 19$ & 369 & 88 & 26 \\
\hline $0,63-1,25$ & $157 \pm 19$ & 368 & 89 & 28 \\
\hline$<0,63$ & $161 \pm 19$ & 391 & 91 & 28 \\
\hline
\end{tabular}

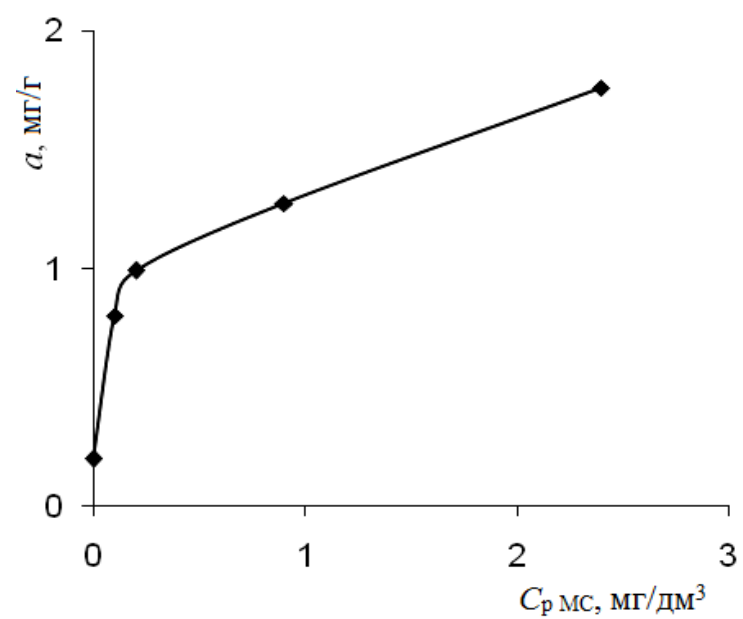

Рис. 2. Ізотерма адсорбції МС гранульованим доменним шлаком, що активований водою протягом 1 доби ( $\left.T=298 \mathrm{~K}, \mathrm{C}_{0} \mathrm{мc}=20 \mathrm{мг/г}\right)$

Величина адсорбції не досягає граничного значення з ростом рівноважної концентрації МС $\left(C_{p}\right)$. Це свідчить про високу ефективність адсорбції з утворенням полімолекулярного шару органічного барвника на поверхні сорбенту.

Ефективність очищення промивних вод з концентрацією МС 20 мг/дм³ перевірялась протягом 5 діб і складала, \%: 1 доба - 97,5; 3 доби - 99,9; 5 діб - 99,95.

Витримка в воді шлаку, який сорбував МС до досягнення максимальної $а$, проводилася протягом 30 діб, після чого МС не було виявлено в контрольних зразках води. Таким чином, ефективність адсорбції підтверджується відсутністю десорбції МС зі шлаку.

Раніше [18] показано, що шлаковий сорбент на основі мінералу діопсиду сорбує органічні 
барвники МС, КЧ та МВ. Спільним у даного сорбенту з досліджуваним в даній роботі сорбентом на основі гранульованого доменного шлаку є наявність гідроксильних і силанольних груп, що утворюються при контакті з водою і обумовлюють прояв негативного заряду поверхні. Пофрарбований іон МС заряджений позитивно і адсорбується переважно на електронегативних (кислотного характеру) адсорбентах. Полярна адсорбція супроводжується обміном іонами між сорбентом і розчином. Утримуванню великого іона барвника на поверхні сорбенту сприяють дисперсійні сили. Адсорбовані ароматичні сполуки мають досить великий постійний дипольний момент за рахунок чого здійснюється індукційна електростатична взаємодія з поверхнею сорбенту. Характер взаємодії шлакових адсорбентів і органічних сполук свідчить про протікання специфічної, незворотньої активованої адсорбції, що підтверджується практичною відсутністю десорбції органічних сполук з відпрацьованого сорбенту. Виявляється хімічна інертність мінералів шлаку 3 одночасним проявом сорбційної активності.

Технологічна схема адсорбційної очистки стічних вод від органічних барвників із забезпеченням замкнутості циклу оборотного водоспоживання. Схема (рис. 3) може використовуватися на підприємствах органічного синтезу і текстильних виробництвах.

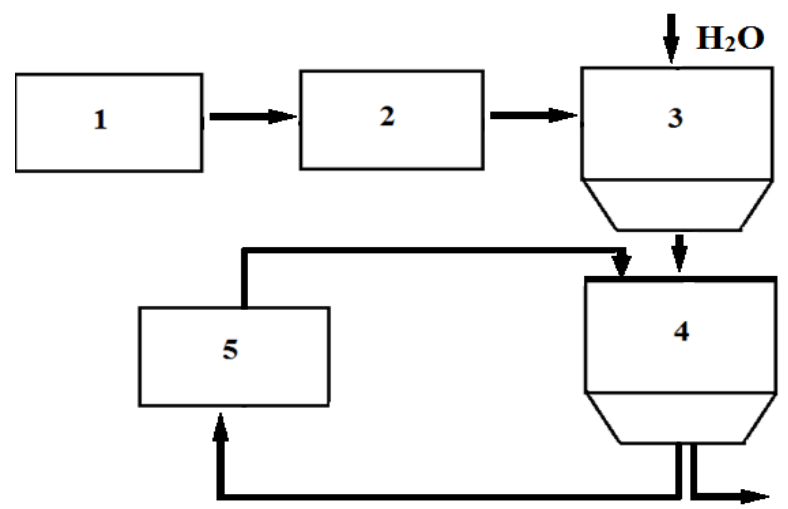

Рис. 3. Технологічна схема адсорбційної очистки стічних вод від органічних барвників шлаковим сорбентом: 1 - відвал шлаку;

2 - аналіз мінерального складу шлаку;

3 - резервуар активації шлаку; 4 - відстійник для знебарвлення стічних вод;

5 - підприємство-споживач

Гранульований доменний шлак з відвалу 1 потрапляє в блок 2 для аналізу мінерального складу. За відповідності мінерального складу необхідним вимогам шлак активується водою в резервуарі 3. Вода може використовуватися багаторазово для активації порцій шлакового сорбенту. Передбачено періодичне коригування обсягу води. Після активації шлаковий сорбент потрап- ляє в резервуар 4 адсорбційної очистки стічних вод, куди надходять пофарбовані стічні води 3 підприємства 5. При проведенні процесу в умовах статичної сорбції на шлаку істотно знижуються концентрації органічних барвників в промислових стічних водах. Період витримки 3 доби. Після закінчення циклу в адсорбері 4 очищена вода надходить до підприємства-споживача в технологічний процес. Цикл оборотного водоспоживання замкнувся.

На очистку 1 м $^{3}$ промивних вод с концентрацією МC 10-20 мг/дм 3 у урахуванням величини адсорбції шлаку за 1 добу a=0,2 мг/г знадобиться 50-100 кг шлаку.

Висновки. Сорбційну активність і ефективність гранульованого доменного шлаку «АрселорМіттал Кривий Ріг» як сорбенту визначають алюмосилікатний склад шлаку, наявність сполучень в аморфному стані, негативний заряд поверхні шлакових частинок, величина адсорбції 2 мг/г, утворення полімолекулярного шару МC на поверхні шлаку, відсутність десорбції МС, радіаційна безпека.

Запропонована адсорбційна очистка стічних вод від органічних барвників дозволить заощадити водні ресурси і вирішити екологічні проблеми накопичення твердих відходів металургії при їх використанні в якості сорбентів. Відсутність десорбції MC з відпрацьованого шлакового сорбенту підтверджує ефективність адсорбційного процесу.

\section{Література:}

1. Борисова В.Ю., Завалюев В.Э., Кондакова Н.В., Хайсерова Л.Я. Анализ сорбционных свойств материалов природного и промышленного происхождения. Фундаментальные исследования. 2016. № 9-2. С. 233-237.

2. Двадненко М.В., Привалова Н.М., Кудаева И.Ю., Степура А.Г. Адсорбционная очистка сточных вод. Современные наукоемкие технологии. 2010. № 10. С. 214-215.

3. Крамер С.М., Терехова М.В., Артамонова И.В. Адсорбция фросфат-ионов на красном шламе. Изв. вузов. Химия и хим. технология. 2017. Т. 60. Вып. 8. С. 80-83. DOI: 10.6060/tcct.2017608.5663.

4. Пугачева И.Н., Карманов А.В., Зуева С.Б., De Michelis I., Ferella F., Молоканова Л.B., Vegliò F. Удаление тяжелых металлов текстильными отходами на основе целлюлозы. Изв. вузов. Химия и хим. технология. 2020. Т. 63. Вып. 2. С. 105-110. DOI: 10.6060/ivkkt.20206302.6098.

5. Зубкова О.С., Алексеев А.И., Залилова М.М. Исследования совместного применения углеродсодержащих и алюминий-содержащих соединений для очистки сточных вод. Изв. вузов. Химия и хим. технология. 2020. Т. 63. Вып. 4. C. 86-91. DOI: 10.6060/ivkkt.20206304.6131. 
6. Гусев Г.И., Гущин А.А., Гриневич В.И., Филиппов Д.В., Извекова Т.В. Физико-химические свойства сорбентов, используемых в очистке воды от нефтепродуктов. Изв. вузов. Химия и хим. технология. 2018. Т. 61. Вып. 7. С. 137-143. DOI: 10.6060/ivkkt.20186107.5686.

7. Tan G., Xue Y., Wan L. Phenol adsorption onto modified industrial solid waste adsorbents in the presence of cationic and anionic surfactant. Intern. Conf. on Computer Science and Electronic Technology (ICCSET 2014). 2014. P. 97-102. DOI: 10.2991/iccset-14.2015.21.

8. Liu X.F., Peng J.H., Wei G.W., Yang C.H., Huang L.Q. Adsorption characteristics of surfactant on slag in alkali activated slag cement system. Applied Mechanics and Materials. 2012. V. 174177. P. 1072-1078. DOI: 10.4028/www.scien tific.net/AMM.174-177.1072.

9. Özcan A., Ömeroğlu Ç., Erdoğan Y., Özcan A. S. Modification of bentonite with a cationic surfactant: An adsorption study of textile dye Reactive Blue 19. J. Hazardous Materials. 2007. V. 140 P. $173-179 . \quad$ DOI: 10.1016/j.jhazmat. 2006.06.138.

10. Lin J.X., Zhan S.L., Fang M.H, Qian X.Q., Yang $\mathrm{H}$. Adsorption of basic dye from aqueous solution onto fly ash. J. Environ. Management. 2007. V. 87. P. 193-200. DOI: 10.1016/j.jenvman. 2007.01.001.

11. Hsue T.C. Adsorption of an acid dye onto coal fly ash. Fuel. 2008. V. 87. P. 3040-3045. DOI:10.1016/j.fuel.2008.03.026.

12. Dizge N., Aydine C., Demirbas E., Kobya M., Kara $S$. Adsorption of reactive dyes from aqueous solutions by fly ash: Kinetic and equilibrium studies. J. Hazardous Materials. 2008. V. 150. P. 737-746. DOI: 10.1016/j.jhazmat.2007.05.027.

13. Pansuk C., Vinitnantharat S. A comparative study of the adsorption of Acid Brown 75 and Direct Yellow 162 onto unmodified and surfactant modified granule developed from coal fly ash. 2nd Intern. Conf. on Environmental Science and Technology IPCBEE. Singapore, IACSIT Press. 2011. V. 6. P. 49-54.

14. Трифонова М.Ю., Доленко С.А., Тарасевич Ю.И., Бондаренко С.В., Жукова А.И. Адсорбция органических анионов из водных растворов слоистыми силикатами, замещенными катионным полиэлектролитом. Химия и технология воды. 2011. Т. 33. № 5. С. 477-487.

15. Грайворонская И.В., Хоботова Э.Б. Эколого-химическая оценка сорбционных свойств металлургических шлаков. Экология и промышленность России. 2012. № 5. С. 31-35. DOI: 10.18412/1816-0395-2012-5-31-35.

16. Хоботова Э.Б., Грайворонская И.В., Ларин В.И. Характеристика металлургических шлаков как адсорбентов и определение направлений их практического использования. Экология и промышленность. 2017. № 1(50). С. 101-105.
17. Хоботова Э.Б., Грайворонская И.В. Вторичное использование металлургических шлаков в качестве сорбентов при очистке сточных вод. Черные металлы. 2019. № 7. С. 55-61.

18. Хоботова Э.Б., Грайворонкая И.В., Игнатенко М.И., Калюжная Ю.С. Адсорбция органических красителей на металлургическом шлаке производства сплава $\mathrm{Fe}-\mathrm{Ni}$. Изв. вузов. Химия и хим. технология. 2020. Т. 63. Вып. 8. С. 103-108. DOI: 10.6060/ivkkt.20206308.6197.

19. JCPDS PDF-1 File. Intern. Committee for Diffraction Data, release 1994 PA, USA. www.ICDD.com

20. Rodriguez-Carvajal J., Roisnel T. FullProf. 98 and WinPLOTR: New Windows 95 / NT Applications for Diffraction. Commission for Powder Diffraction, Intern. Union of Crystallography, Newsletter. 1998. N 20.

21. Нормы радиационной безопасности (НРБ-99/2009). Санитарные правила и нормативы СанПиН 2.6.1.2523-09. М.: Федеральный центр гигиены и эпидемиологии Роспотребнадзора. 2009. $100 \mathrm{c}$.

22. Справочник химика 21. Химия и химическая технология [Электронный ресурс]. URL: https://chem21.info/info/1830290/.

23. Белопухов С.Л., Яшин М.А., Слюсарев В.И., Нефедьева Е.Э., Шайхиев И.Г. Технологии очистки сточных вод текстильных производств для снижения поступления токсикантов в природные поверхностные воды. Вестник технологического университета. 2015. Т. 18, № 5. С. 199-204.

24. Утебаева А.А., Бахов Ж.К., Абдуова А.А., Абдикеримов С.Ж., Джусипбекова Г.Т., Бейсенбаева Ш.Г., Куралбаева А.Н. Комбинированная технологическая схема очистки сточных вод текстильных производств. Технология текстильной промышленности. 2019. №1. С. 312-318.

25. Хоботова Э.Б., Калмыкова Ю.С., Игнатенко М.И., Ларин В.И. Естественные радионуклиды доменных шлаков. Черные металлы. 2017. № 1. C. 23-28.

\section{References}

1. Borisova V.Yu., Zavalyuev V.E., Kondakova N.V., Khaiserova L.Ya. Analysis of the sorption properties of materials of natural and industrial origin. Fundamental'nyye issledovaniya. 2016. N 92. P. 233-237. (in Russian).

2. Dvadnenko M.V., Privalova N.M., Kudaeva I.Yu., Stepura A.G. Wastewater adsorption treatment. Sovremennyye naukoyemkiye tekhnologii. 2010. N 10. C. 214-215. (in Russian).

3. Kramer S.M., Terekhova M.V., Artamonova I.V. Adsorption of phosphate ions on red sludge. Izv. Vyssh. Uchebn. Zaved. Khim. Khim. Tekhnol. [Russ. J. Chem. \& Chem. Tech.]. 2017. V. 60. N 8. P. 80 83 (in Russian). DOI: 10.6060/tcct.2017608.5663. 
4. Pugacheva I.N., Karmanov A.V., Zueva S.B., De Michelis I., Ferella F., Molokanova L.V., Vegliò F. Heavy metal removal by cellulose-based textile waste product. Izv. Vyssh. Uchebn. Zaved. Khim. Khim. Tekhnol. [Russ. J. Chem. \& Chem. Tech.]. 2020. V. 63. N 2. P. 105-110. DOI: $10.6060 /$ ivkkt.20206302.6098.

5. Zubkova O.S., Alekseev A.I., Zalilova M.M. Research of combined use of carbon and aluminum compounds for wastewater treatment. Izv. Vyssh. Uchebn. Zaved. Khim. Khim. Tekhnol. [Russ. J. Chem. \& Chem. Tech.]. 2020. V. 63. N 4. P. 86-91. DOI: 10.6060/ivkkt.20206304.6131.

6. Gusev G. I., Gushchin A. A., Grinevich V. I., Izvekova T. V., Fillipov D. V. Physical and chemical properties of sorbents used for wastewater purification from oil products. Izv. Vyssh. Uchebn. Zaved. Khim. Khim. Tekhnol. [Russ. J. Chem. \& Chem. Tech.]. 2018. V. 61. N 7. P. 137-143 (in Russian). DOI:10.6060/ivkkt.20186107.5686.

7. Tan G., Xue Y., Wan L. Phenol adsorption onto modified industrial solid waste adsorbents in the presence of cationic and anionic surfactant. Intern. Conf. on Computer Science and Electronic Technology (ICCSET 2014). 2014. P. 97-102. DOI: 10.2991/iccset-14.2015.21.

8. Liu X.F., Peng J.H., Wei G.W., Yang C.H., Huang L.Q. Adsorption characteristics of surfactant on slag in alkali activated slag cement system. Applied Mechanics and Materials. 2012. V. 174177. P. 1072-1078. DOI: 10.4028/www.scientific. net/AMM.174-177.1072.

9. Özcan A., Ömeroğlu Ç., Erdoğan Y., Özcan A. S. Modification of bentonite with a cationic surfactant: An adsorption study of textile dye Reactive Blue 19. J. Hazardous Materials. 2007. V. 140 . P. 173-179. DOI: 10.1016/j.jhazmat. 2006.06.138.

10. Lin J.X., Zhan S.L., Fang M.H, Qian X.Q., Yang $\mathrm{H}$. Adsorption of basic dye from aqueous solution onto fly ash. J. Environ. Management. 2007. V. 87. P. 193-200. DOI: 10.1016/j.jenvman. 2007.01.001.

11. Hsue T.C. Adsorption of an acid dye onto coal fly ash. Fuel. 2008. V. 87. P. 3040-3045. DOI:10.1016/j.fuel.2008.03.026.

12. Dizge N., Aydine C., Demirbas E., Kobya M., Kara S. Adsorption of reactive dyes from aqueous solutions by fly ash: Kinetic and equilibrium studies. J. Hazardous Materials. 2008. V. 150. P. 737-746. DOI: 10.1016/j.jhazmat.2007.05.027.

13. Pansuk C., Vinitnantharat S. A comparative study of the adsorption of Acid Brown 75 and Direct Yellow 162 onto unmodified and surfactant modified granule developed from coal fly ash. 2nd Intern. Conf. on Environmental Science and Technology IPCBEE. Singapore, IACSIT Press. 2011. V. 6. P. 49-54.
14. Trifonova M.Yu., Dolenko S.A., Tarasevich Yu.I., Bondarenko S.V., Zhukova A.I. Adsorption of organic anions from aqueous solutions by layered silicates substituted with cationic polyelectrolyte. Khimiya i tekhnologiya vody. 2011. V. 33. N 5. P. 477-487. (in Russian).

15. Hraivoronska I.V., Khobotova E.B. Ecological and chemical assessment of the sorption properties of metallurgical slags. Ekologiya i promyshlennost' Rossii. 2012. N 5. P. 31-35. DOI:10.18412/18160395-2012-5-31-35. (in Russian).

16. Khobotova E.B., Hraivoronska I.V., Larin V.I. Characterization of metallurgical slags as adsorbents and determination of the directions of their practical use. Ekologiya i promyshlennost'. 2017. N 1(50). C. 101-105. (in Russian).

17. Khobotova E.B., Hraivoronska I.V. Recycling of metallurgical slag as sorbents in wastewater treatment. Chernyye metally. 2019. N 7. P. 55-61 (in Russian).

18. Khobotova E. B., Hraivoronska I. V., Ihnatenko M. I., Kaliuzhna lu. S. Adsorption of organic dyes on metallurgical slag of $\mathrm{Fe}-\mathrm{Ni}$ alloy production Izv. Vyssh. Uchebn. Zaved. Khim. Khim. Tekhnol. [Russ. J. Chem. \& Chem. Tech.]. 2020. V. 63. N 8. P. 103-108. DOI: $10.6060 /$ ivkkt. 20206308.6197.

19. JCPDS PDF-1 File. Intern. Committee for Diffraction Data, release 1994 PA, USA. www.ICDD.com

20. Rodriguez-Carvajal J., Roisnel T. FullProf. 98 and WinPLOTR: New Windows 95 / NT Applications for Diffraction. Commission for Powder Diffraction, Intern. Union of Crystallography, Newsletter. 1998. N 20.

21. Radiation safety norms (NRB-99/2009): Sanitary-epidemiological rules and standards. M.: Federalny tsentr gigieny i epidemiologii Rospotrebnadzora. 2009. 100 p. (in Russian).

22. Chemist's Handbook 21. Chemistry and Chemical Technology [Electronic resource]. URL: https://chem21.info/info/1830290/. (in Russian).

23. Belopukhov S.L., Yashin M.A., Slyusarev V.I., Nefedieva E.E., Shaikhiev I.G. Wastewater treatment technologies for textile industries to reduce the intake of toxicants into natural surface waters. Technological University Bulletin. 2015. Vol. 18, N. 5. P. 199-204. (in Russian).

24. Utebayeva A.A., Bakhov Zh.K., Abduova A.A., Abdikerimov S.Zh., Dzhusipbekova G.T., Beisenbaeva Sh.G., Kuralbaeva A.N. Combined technological scheme for wastewater treatment in textile industries. Textile industry technology. 2019. N. 1. P. 312-318. (in Russian).

25. Khobotova E.B., Kalmykova Y.S., Ihnatenko M.I., Larin V.I. Natural radionuclides of blast furnace slags. Chernyye metally. 2017. N 1. P. 23-28. (in Russian). 


\section{Аннотация}

\section{Гранулировіанный доменный шлак как сорбент органических красителей}

\section{И.В. Грайворонская, Э.Б. Хоботова, В.В. Даценко, И.А. Черепнёв}

Определены свойства гранулированного доменного шлака «АрселорМиттал Кривой Рог», обусловливающие его сорбционную активность. В составе фракций шлака идентифицированы минералы: окерманит $\mathrm{Ca}_{2} \mathrm{MgSi}_{2} \mathrm{O}_{7}$, геленит $\mathrm{Ca}_{2} \mathrm{Al}\left(\mathrm{Al}, \mathrm{Si}_{2} \mathrm{O}_{7}\right.$, ранкинит $\mathrm{Ca}_{3} \mathrm{Si}_{2} \mathrm{O}_{7}$, псевдоволластонит $\mathrm{CaSiO}_{3}$, мервинит $\mathrm{Ca}_{3} \mathrm{MgSi}_{2} \mathrm{O}_{8}$, микроклин $\mathrm{KAISi}_{3} \mathrm{O}_{8}$, кальцит $\mathrm{CaCO}_{3}$, ольдгамит $\mathrm{CaS}$ с содержанием алюмосиликатов кальция и магния $>50 \%$. Некоторые фразы находятся в аморфном сорбционно-активном состоянии. Показана целесообразность активации водой в течение 1 суток, в результате которой на поверхности образуются и диссоциируют гидроксильные и силанольные группы с формированием отрицательного заряда поверхности шлаковых частиц, что характерно для алюмосиликатов Са и $\mathrm{Mg}$, а также минералов кальцита и ольдгамита. Форма изотермы адсорбции свидетельствует об образовании полимолекулярных слоев органического красителя метиленового синего (МС), что увеличивает эфффективность шлакового сорбента. Величина адсорбции МС не менее 2 мг/г. Показано отсутствие десорбции МС из шлака, что обеспечивает безопасность как захоронения отработанного сорбента, так и его утилизации в качестве наполнителя строительных материалов. Доказана радиационная безопасность шлака. Удельная эфффективная активность фрракций шлака не превышает 370 Бк/кг, что разрешает их использование в качестве технических материалов без ограничений. Предложена технологическая схема адсорбционной очистки сточных вод предприятий органического синтеза и текстильной промышленности, содержащих органические красители, с помощью шлакового сорбента. Стадии технологического процесса: поступление шлака из отвала, анализ минерального состава шлака, водная активация шлака, статическая сорбция красителей в отстойнике, дальнейшая утилизация шлака и поступление очищенных вод в первичное производство. Технология предусматривает удаление органических красителей из сточных вод и их повторное использование, что обеспечивает замкнутость цикла оборотного водопотребления, отсутствие расхода химических реагентов на активацию шлакового сорбента, улучшение экологической ситуации в местах расположения шлаковых отвалов за счет использования шлаков в качестве сорбентов.

Ключевые слова: сорбция, гранулированный доменный шлак, органические красители, величина адсорбции, активация шлака, адсорбционный процесс, очистка раствора

\section{Abstract}

\section{Granulated blast-furnace slag as sorbeht of organic dyes}

\section{I.V. Hraivoronska, E.B. Khobotova, V.V. Datsenko, I.A. Cherepnov}

The properties of granulated blast-furnace slag from "ArcelorMittal Kryvyi Rih", which stipulate its sorption activity, have been determined. The following minerals were identified in the slag fractions: akermanite $\mathrm{Ca}_{2} \mathrm{MgSi}_{2} \mathrm{O}_{7}$, helenite $\mathrm{Ca}_{2} \mathrm{Al}(\mathrm{Al}, \mathrm{Si})_{2} \mathrm{O}_{7}$, rankinite $\mathrm{Ca}_{3} \mathrm{Si}_{2} \mathrm{O}_{7}$, pseudo-wollastonite $\mathrm{CaSiO}_{3}$, merwinite $\mathrm{Ca}_{3} \mathrm{MgSi}_{2} \mathrm{O}_{8}$, microcline $\mathrm{KAISi}_{3} \mathrm{O}_{8}$, calcite $\mathrm{CaCO}_{3}$, aldhamite $\mathrm{CaS}$ with $>50 \%$ of calcium and magnesium aluminosilicates. Some phases are in an amorphous sorption-active state. The expediency of activation with water for 1 day is shown, due to which hydroxyl and silanol groups are formed and dissociated on the surface with the formation of a negative charge on the surface of slag particles, which is typical for $\mathrm{Ca}$ and $\mathrm{Mg}$ aluminosilicates. The shape of the adsorption isotherm indicates the formation of polymolecular layers of the methylene blue (MB) organic dye, which increases the efficiency of the slag sorbent. The adsorption value of MB is not less than $2 \mathrm{mg} / \mathrm{g}$. There is obviously no desorption of MB from the slag, which ensures the safety of both the disposal of the waste sorbent and its utilization as a filler for construction materials. The radiation safety of the slag has been proven. The specific effective activity of slag fractions does not exceed $370 \mathrm{Bg} / \mathrm{kg}$, which allows using them as technical materials without restrictions. A technological scheme of adsorption purification of wastewaters from organic synthesis enterprises and textile industry containing organic dyes, is suggested using a slag sorbent. The stages of the technological process are the following: receiving the slag from the dump, analysis of the mineral composition of the slag, water activation of the slag, static sorption of dyes in the sump, further utilization of the slag and the inflow of purified water into the primary production. The technology provides for the removal of organic dyes from wastewater and its repeated usage, which ensures the closed cycle of water reuse, no need for chemical reagents for the activation of the slag sorbent, improvement of the environmental situation in the locations of the slag dumps due to the use of slags as sorbents.

Keywords: sorption, granular blast-furnace slag, organic dyes, adsorption value, slag activation, adsorption process, solution purification

Бібліографічне посилання/ Bibliography citation: Harvard

Hraivoronska, I. V. et al. (2020) 'Granulated blast-furnace slag as sorbeht of organic dyes', Engineering of nature management, (4(18), pp. 53 - 59.

Подано до редакції / Received: 06.10.2020 